\title{
Are energy and protein targets being met in the ICU?
}

\author{
R Booth ${ }^{*}$, L Morgan \\ From ESICM LIVES 2015 \\ Berlin, Germany. 3-7 October 2015
}

\section{Background}

Multiple barriers exist to achieving energy and protein targets in the critically ill. Elke et al [1] used data from ICU's worldwide which estimated average energy delivery of only $1057 \mathrm{kcals} /$ day and protein delivery $49 \mathrm{~g} / \mathrm{d}(0.7 \mathrm{~g} /$ $\mathrm{kg} / \mathrm{d}$ ). Weijs et al [2] demonstrated that meeting energy and protein requirements is associated with decreased mortality. Local data from 2012 found an average delivery of $1424 \mathrm{kCal}$ and $56.8 \mathrm{~g}$ protein $/ \mathrm{d}(0.75 \mathrm{~g} / \mathrm{kg} / \mathrm{d})$ once at target rate (TR) and that $40 \%$ of patients were taking > 5 days to reach TR. As a result alterations were made to the ICU feeding protocol; 1.GRV threshold increased to $300 \mathrm{ml}, 2$. Daily monitoring of energy and protein provision, 3.Introduction of protein modules.

\section{Objectives}

To assess energy and protein delivery for enterally fed patients in a 16 bed ICU following implementation of modifications to protocol, and comparison with historical controls.

\section{Methods}

A retrospective, case control study over 2 weeks in the ICU. Energy and protein intakes recorded from admission up until day 20; or until discharge from critical care, removal of the enteral feeding tube or death.

\section{Results}

20 patients, 11 male +9 female, aged 23-84 yrs. Mean weight $80 \mathrm{~kg}+$ BMI $27.8 \mathrm{~kg} / \mathrm{m}^{2}\left(19-41 \mathrm{~kg} / \mathrm{m}^{2}\right) .79 \%$ of patients had EN initiated within $48 \mathrm{hrs}$ and $95 \%$ within 72 hrs. Mean time to TR was 4 days. $19 \%$ of patients took $>5$ days to reach TR. Mean daily energy delivery $1428 \mathrm{kCal}+93 \%$ energy requirements met. Mean daily

\footnotetext{
Royal Gwent Hospital, Dietetics, Newport, United Kingdom
}

protein delivery $64.7 \mathrm{~g}(0.86 \mathrm{~g} / \mathrm{kg} / \mathrm{d})+71 \%$ of protein requirements met.

\section{Conclusions}

Increasing GRV threshold improved the number of patients reaching TR in 5 days by $50 \%$... Energy delivery was similar to 2012 but higher than those reported by Elke et al [1]. However \% of energy requirements met once at TR increased by $4 \%$ from 2012 . Protein delivery increased by $8 \mathrm{~g}$ protein $/ \mathrm{d}(13 \%)$ and was $15.7 \mathrm{~g}(22 \%)$ higher than stated by Elke et al. The use of protein modules and daily monitoring improves energy and protein delivery. However, protein is still falling short of the recommended $1.5 \mathrm{~g} / \mathrm{kg} /$ day [3] due to non-feed sources of energy and high requirements in the obese; $\geq 2-2.5 \mathrm{~g} / \mathrm{kg}$ IBW (ASPEN, 2009).

\section{Published: 1 October 2015}

\section{References}

1. Elke G, Wang M, Weiler N, Day AG, Heyland DK: Close to recommended caloric and protein intake by enteral nutrition is associated with better clinical outcome of critically ill septic patients: secondary analysis of a large international nutrition database. Crit Care 2014, 18:1-R29.

2. Weijs PJ, Stapel SN, de Groot SD, Driessen RH, de Jong E, Girbes AR, et al: Optimal Protein and Energy Nutrition Decreases Mortality in Mechanically Ventilated, Critically III Patients A Prospective Observational Cohort Study. JPEN J Parenter Enteral Nutr 2012, 36(1):60-68.

3. Singer $P$, Hiesmayr M, Biolo G, Felbinger TW, Berger MM, Goeters C, et al: Pragmatic approach to nutrition in the ICU: Expert opinion regarding which calorie protein target. Clin Nutr 2014, 33(2):246-251.

4. Martindale RG, McClave SA, Vanek VW, McCarthy M, Roberts P, Taylor B, et al: Guidelines for the provision and assessment of nutrition in nutrition support therapy in the adult critically ill patient: Society of Critical Care Medicine (SCCM) and American Society for Parenteral and Enteral Nutrition (A.S.P.E.N.). JPEN J Parenter Enteral Nutr 2009, 33(3):277-316.

doi:10.1186/2197-425X-3-S1-A578

Cite this article as: Booth and Morgan: Are energy and protein targets being met in the ICU? Intensive Care Medicine Experimental 2015 3(Suppl 1):A578.

\section{SpringerOpen ${ }^{\circ}$}

C 2015 Booth and Morgan This is an Open Access article distributed under the terms of the Creative Commons Attribution License (http://creativecommons.org/licenses/by/4.0), which permits unrestricted use, distribution, and reproduction in any medium, provided the original work is properly cited. 